\title{
Bazı fasulye genotiplerinin Eskişehir koşullarına uyum yetenekleri*
}

\author{
Tolga IYYIGÜN@1, Nihal KAYAN $D_{2}$ \\ ${ }^{1}$ METGEN Tohumculuk Ltd. Ști., 34710, İstanbul \\ ${ }^{2}$ Eskișehir Osmangazi Üniversitesi, Ziraat Fakültesi, Tarla Bitkileri Bölümü, 26160, Eskişehir \\ *Birinci yazarın yüksek lisans çalıșmasından alınmıștır.
}

Alınış tarihi: 26 Temmuz 2019, Kabul tarihi: 25 Kasım 2019

Sorumlu yazar: Nihal KAYAN, e-posta: nkayan@ogu.edu.tr

\section{Öz}

Araștırma 2011-2012 yıllarında Eskișehir Osmangazi Üniversitesi Ziraat Fakültesi deneme arazilerinde bazı ticari kuru fasulye çeşitlerinin verim ve verim unsurlarını incelemek amacıyla yürütülmüştür. Yürütülen çalışma, tesadüf blokları deneme desenine göre 3 tekerrürlü olarak kurulmuş olup, araştırmada tane için tescil edilmiş Nassau, Balkız, Gina, Bourgondia, Magnum, Başpınar, Romano çeşitleri ile SF08/03 nolu hat kullanılmıştır. Sonuç olarak Balkız çeşidinin tane verimi ve önemli verim unsurları bakımından diğer çeşitlere oranla daha üstün performans gösterdiği ve bölge için önerilebileceği belirlenmiştir. Magnum çeşidi ise yaşanan yüksek sıcaklıklarda biyolojik verim ve tane verimini koruyabildiği için dikkat çekicidir.

Anahtar kelimeler: Çeşit, fasulye, genotip, verim unsurlarl, verim

\section{Adaptability of some bean genotypes to Eskişehir conditions}

\author{
Abstract \\ This researchs were conducted at Applying Research \\ Area, Faculty of Agriculture, University of Eskișehir \\ Osmangazi in 2011 and 2012. The purpose of this \\ study was to identify to investigate the yield and \\ yield components of commercial dry bean varieties. \\ The experimental design was randomized complete \\ block design with three replicates. Seven different \\ commercial dry bean cultivars (Nassau, Balkı, Gina, \\ Bourgondia, Magnum, Başpınar, Romano-26) and \\ one bean lines (SF08/03) were used as a material. \\ According to results; cultivar Balkız is superior to
}

other cultivars for some yield components and yield and it can be suggested for the region. Magnum variety is important because it can maintain biological yield and grain yield at high temperatures.

Key words: Cultivars, bean, genotypes, yield components, yield

\section{Giriş}

Kökeni Orta Amerika olan fasulye 250 yıl önce Anadolu'ya getirilmiş ve bölgede geniş alanlarda üretimi yapılmıştır. Özellikle son on yılda, yüksek protein içermesinin yanı sıra diyetsel lifleri bünyesinde bulundurması, önemli minareller ve bazı vitaminler bakımından zengin olmasının daha iyi anlaşılmasından dolayı gelişmiş ülkelerde tüketimi artış göstermiştir. Zaman ilerledikçe, kalp hastalıkları, kanser ve obeziteyi önlemede, baklagillerin içerdiği besin maddelerinin önemi daha da iyi anlaşılmaktadır (Adak ve ark., 2015).

Fasulye tarımı dünya üzerinde ılıman bölgelerde yaygındır ve \% 94 gibi yüksek bir oranla Asya ve Güney Amerika kıtalarında tarımı yapılmaktadır (Demircan, 2018). 2017 yılında dünyada kuru fasulyenin toplam ekim alanı 36 milyon ha, toplam üretimi 26 milyon ton olup, ortalama verimi 861 $\mathrm{kg} /$ ha'dır. Dünya ülkelerine göre fasulye ekim alanı ve üretimine bakıldığında ilk sırada 15 milyon ha ekim alanı ve 6 milyon ton üretim ile Hindistan'ın yer aldığı görülmektedir. Hindistan'ı 3 milyon ha ekim alanı ve 5 milyon ton üretim ile Myanmar ve 2 milyon ha ekim alanı ve 3 milyon ton üretim ile Brezilya takip etmektedir. Ülkemizde 2017 yllında fasulye ekim alanı 89 bin ha, üretimi 239 bin ton ve verimi 2665 kg/ha'dır (FAO, 2017). Eskișehir'de 
kuru fasulye ekim alanı 299 ha ve üretim miktarı 574 tondur (TUİK, 2017).

Her fasulye çeşidinin değişik ekolojik koşullara uyum sağlaması genetik yapısından dolayı değişiklik göstermektedir. Fasulye genotipleri arasında verim bakımından farklılıklar olmasının yanı sıra istedikleri ekolojik faktörler bakımından da önemli farlılıklar bulunmaktadır (Şehirali, 1988). Fasulyede verimin artırılması, kültürel uygulamalar ile birlikte bölgeye uygun çeşitlerin saptanarak yetiştirilmesine bağlıdır (Pekşen, 2005; Öner ve ark., 2016). Günümüzde artık tarım alanlarını artırabilme olanağı olmadığından, bitkisel üretimdeki artışlar ancak birim alan veriminde artış sağlayarak gerçekleşebilecektir. Birim alan verimini artırabilmek için uygulanan etkili yollardan birisi ise bölgenin ekolojik koşullarına uygun verimi yüksek çeşitleri ekmektir. Anlarsal ve ark. (2000), Çukurova koşullarında 7 bodur fasulye ve 8 sarılıcı fasulye çeşidiyle yürüttükleri denemelerinde, 7 bodur fasulye çeşidinde çiçeklenmeye kadar geçen gün sayısının 30-37 gün, bitki boyunun 38.6-50.7 cm, ilk bakla yüksekliğinin 13.3-18.1 $\mathrm{cm}$, bitkide dal sayısının 6.3-10.2 adet, bitkide bakla sayısının 11.415.2 adet, baklada tane sayısının 2.3-3.0 adet, bitkide tane sayısını 25.2-47.5 adet, bitkide tane veriminin 7.3-14.3 g, 100 tane ağırlığını 22.3-33.6 g ve tane verimini $574-1196 \mathrm{~kg} / \mathrm{ha}$ arasinda değiştiğini tespit etmişlerdir. Elkoca ve Kantar (2004), Erzurum ekolojik koşullarında, Erzurum merkez ve Pasinler deneme istasyonu olmak üzere iki farklı lokasyonda 4 fasulye hattı ve 2 tescilli fasulye çeşidini denemişler, bitki boyunun 44.1-76.8 $\mathrm{cm}$, bitkide dal sayısının 3.0-4.2 adet, bitkide bakla sayısının 11.3-17.3 adet, baklada tane sayısının 3.54.2 adet, bin tane ağırlığının 283.4-426.6 g ve tane veriminin $1842-2540 \mathrm{~kg} / \mathrm{ha}$ arasında değiștiğini saptamışlardır. Pekşen (2005), Samsun ekolojik koşullarında 4 fasulye çeşidi ve 2 populasyon ile denemelerini yürütmüşler, çiçeklenme periyodunun 23.50-64.83 gün, bitki boyunun $24.55-72.28 \mathrm{~cm}$, ilk bakla yüksekliğinin $6.90-12.65 \mathrm{~cm}$, bitkide bakla sayısının 7.21- 13.45 adet, baklada tane sayısının 3.24-6.06 adet, 100 tane ağırlığının 17.78-52.88 g, bitki bașına tane verimlerinin 4.56-14.90 g arasında değiştiği tespit etmiştir. En yüksek hektara tane verimleri ise Yunus-90 (2316 kg/ha) ve Şahin-90 (1860 kg/ha) çeşitlerinden elde edilmiştir. Ülker (2008), Sarayönü ve Çumra olmak üzere iki farklı lokasyonda yürüttüğü denemelerinde 19 fasulye genotipi ile çalışmış, bitkide dal sayılarının 3.39 ile
4.56 adet, bitki boylarının 38.56 ile $86.72 \mathrm{~cm}$, çiçeklenme sürelerinin 53.50 ile 72.50 gün, bitkide bakla sayıları 11.61-25.17 adet, baklada tane sayıları 3.53-4.89 adet, bitkide tane sayları 46.50-116.45 adet, biyolojik verimleri 4562-10936 kg/ha, tane verimleri $1629-4768 \mathrm{~kg} / \mathrm{ha}$, hasat indeksleri \% 34.63-46.87 ve bin tane ağırlıkları 249.07-455.00 g arasında değişim gösterdiğini bildirmiştir. Ceyhan ve ark. (2009), 16 fasulye genotipi kullanarak Konya koşullarında yürüttükleri denemelerinde bitkide dal sayısını 5.2 -11.9 adet, bitki boyunu $44.1-84.8 \mathrm{~cm}$, bitkide bakla sayısının 12.3 - 32.0 adet, baklada tane sayısının 4.0 - 6.0 adet, bin tane ağırlığının 218.0 $467.1 \mathrm{~g}$, biyolojik verimin $3222-8500 \mathrm{~kg} / \mathrm{ha}$, tane veriminin 1112 - $2994 \mathrm{~kg} /$ ha ve hasat indeksinin \% 21.2 - 40.1 arasında değiștiğini bildirmişlerdir. Güneş (2011), Van'ın Gevaş ilçesinde 23 fasulye genotipi ile denemelerini yürütmüşler, çıkış süresini 10.0-15.6 gün, çiçeklenme süresini 36-56 gün, bitki boyunu 56.5-287.8 cm, bitkide bakla sayısı 16-46 adet, baklada tane sayısı 3.12-5.76 adet ve bin tane ağırlığı 206.0-696.1 g ve tane verimleri 1690-5121 $\mathrm{kg} / \mathrm{ha}$ arasında değişim gösterdiğini bildirmiştir. Varankaya (2011), Yozgat ekolojik koşullarında 22 fasulye genotipini denemişler, bitkide bakla sayılarının 7.45 ile 18.33 adet, baklada tane sayılarının 2.35 ile 3.68 adet, bitkide tane sayılarının 21.78 ile 63.44 adet, yüz tane ağırlıklarının 25.92 ile $46.90 \mathrm{~g}$ ve tane verimlerinin 1504 ile $4007 \mathrm{~kg} / \mathrm{ha}$ arasında saptandığını bildirmiştir. Elkoca ve Çınar (2015), Erzurum ekolojik koşullarında 8 fasulye çeşidi ve 7 fasulye hattı ile denemelerini yürütmüşler, çıkış süresinin 16.00-19.3 gün, çiçeklenme süresinin 34.0-67.7 gün, bitki boyunun $37.7-50.5 \mathrm{~cm}$, ilk bakla yüksekliğinin $12.9-19.7 \mathrm{~cm}$, bitki başına dal sayısının 2.1-3.6 adet, bitkide bakla sayısının 6.5-14.1 adet, baklada tane sayısının 3.475.07 adet, yüz tane ağırlığının 34.6-99.8 g, hasat indeksinin \% 26.8-45.4 ve tane veriminin 924-1954 $\mathrm{kg} / \mathrm{ha}$ arasında değiştiğini bildirmişlerdir.

Orta Anadolu Bölgesi ülkemiz kuru fasulye üretiminin yıllara göre değişmekle birlikte \%4060’nı karşılamaktadır (Demircan, 2018). Ülkemizdeki kuru fasulye üretimi bakımından en fazla ekiliş alanına sahip illerin Konya (19.143 ha), Karaman (10.370 ha), Nevşehir (8.119 ha), Niğde (8.092 ha), Bitlis (6.282 ha) ve Erzincan (3.067 ha) olduğu görülmektedir (TUIK, 2017). Fasulye yetiştiriciliğinin yoğun olarak yapıldığı yerlerde herhangi bir yılda hastallk ve zararlıların yoğun görülmesi ya da iklim şartlarında yaşanabilen olumsuzluklar verimi ve dolayısıyla da ülke toplam 
fasulye üretiminde önemli azalışların meydana gelmesi olasılığını da beraberinde getirmektedir. $\mathrm{Bu}$ risklerin giderilebilmesi için, her bölge için verim ve adaptasyon yeteneği yüksek çeşit geliştirme çalışmalarının yapılmasının yanı sıra üstün özelliklere sahip olan çeşitlerin üreticiye ulaştırılması ve fasulye üretiminin daha geniş alanlara yayılması büyük önem taşımaktadır. $\mathrm{Bu}$ nedenle, Eskişehir bölgesinde kuru tane üretimi amaciyla ekilen fasulye çeşitlerinin verim potansiyellerinin incelenerek bölgeye iyi adapte olmuş yüksek verimli çeşitlerin belirlenmesi, bölgede kuru fasulye tarımının yaygınlaşmasına katkıda bulunacağı düşünülmektedir. $\mathrm{Bu}$ amaçla araştırmada, Eskişehir koşullarında bodur karakterdeki, bazı ticari fasulye genotiplerinin tane verimleri ve verim unsurlarını belirleyerek, bölge koşullarına uygun çeşit ya da çeşitler tespit edilmeye çalışılmıştır.

\section{Materyal ve Yöntem}

$\mathrm{Bu}$ araștırma 2011-2012 yılları bitki yetiștirme döneminde iki yıl süre ile Eskişehir Osmangazi Üniversitesi Ziraat Fakültesi deneme tarlalarında yürütülmüştür. Eskişehir, Orta Anadolu Bölgesinin Batı Geçit kuşağında yer alıp denizden yüksekliği 798 metredir. Denemenin kurulduğu bölge $30^{\circ} 28^{\prime}$
Doğu boylamı ile $39^{\circ} 45^{\prime}$ Kuzey enlemlerinde bulunmaktadır.

Deneme alanından toprak analizi için örnekler alınmış ve T. C. Tarım ve Köyişleri Bakanlığı Eskișehir Toprak ve Su Kaynakları Araștırma Enstitüsü'nde analizleri yapılmıştır (Anonim, 2012). Toprak analizi sonuçlarına göre; araştırma alanı toprakları her iki yılda da hafif alkali, tuzsuz, birinci yıl kireçli ikinci yıl ise orta kireçlidir. Organik madde birinci yılda çok az ikinci yılda az olarak bulunmuştur. Besin elementleri bakımından fosfor az düzeyde, potasyum birinci yll az ikinci yıl yeterli düzeydedir (Çizelge 1).

Eskișehir Meteoroloji Bölge Müdürlüğü'nden temin edilen uzun yıllar ve araştırmanın yürütüldüğü yıllara ait iklim verileri Çizelge 2'de sunulmuştur. Araştırmanın yürütüldüğü 2011 yılı bitki büyüme döneminde yağışın uzun yıllar ortalamasına göre yüksek olduğu, ikinci yılda ise bölgenin uzun yıllar ortalamasına yakın bir yağış alındığı görülmektedir. Araștırmanın ikinci yılında ortalama sıcaklık, hem birinci yıla hem de uzun yıllara oranla daha yüksek olmuştur. Birinci yılda ortalama nispi nem uzun yıllara ait değerlere yakın bulunurken, ikinci yılda nispi nemin biraz düşük olduğu kaydedilmiştir.

Çizelge 1. Deneme alanı topraklarının bazı fiziksel ve kimyasal özellikleri

\begin{tabular}{ccccccc}
\hline Yll & $\begin{array}{c}\text { Derinlik } \\
(\mathrm{cm})\end{array}$ & $\mathrm{pH}$ & $\begin{array}{c}\text { Kireç } \\
\left(\% \mathrm{CaCO}_{3}\right)\end{array}$ & $\begin{array}{c}\text { Tuzluluk } \\
(\%)\end{array}$ & $\begin{array}{c}\text { Organik } \\
\text { Madde }(\%)\end{array}$ & $\begin{array}{c}\mathrm{P}_{2} \mathrm{O}_{5} \\
(\mathrm{~kg} / \mathrm{ha})\end{array}$ \\
\hline 2011 & $0-30$ & 8.09 & 3.63 & 0.024 & 0.91 & 64.1 \\
2012 & $0-30$ & 7.71 & 5.54 & 0.074 & 2.09 & 1247 \\
$(\mathrm{~kg} / \mathrm{ha})$
\end{tabular}

Çizelge 2. Denemenin yürütüldüğü Eskișehir ilinin 2011 ve 2012 yıllarına ve uzun yıllara ait bazı iklim değerleri

\begin{tabular}{|c|c|c|c|c|c|c|c|c|c|}
\hline \multirow{2}{*}{ Aylar } & \multicolumn{3}{|c|}{ Yağıș (mm) } & \multicolumn{3}{|c|}{ Sicaklık $\left({ }^{\circ} \mathrm{C}\right)$} & \multicolumn{3}{|c|}{ Nispi nem (\%) } \\
\hline & 2011 & 2012 & UY & 2011 & 2012 & UY & 2011 & 2012 & UY \\
\hline Mayıs & 92.3 & 50.6 & 40.0 & 13.7 & 15.5 & 14.9 & 64.9 & 62.6 & 59.5 \\
\hline Haziran & 32.0 & 12.6 & 23.7 & 18.1 & 21.7 & 19.1 & 60.3 & 48.9 & 55.2 \\
\hline Temmuz & 20.0 & 12.3 & 13.1 & 23.4 & 24.0 & 22.1 & 51.4 & 49.4 & 51.9 \\
\hline Ağustos & 2.2 & 42.8 & 9.2 & 20.6 & 21.7 & 21.8 & 54.7 & 48.4 & 53.6 \\
\hline Eylül & 7.1 & 0.3 & 18.1 & 18.3 & 19.1 & 16.7 & 52.7 & 52.7 & 58.4 \\
\hline Ort. & & & & 18.8 & 20.4 & 18.9 & 56.8 & 52.4 & 55.7 \\
\hline Toplam & 153.6 & 118.6 & 104.1 & & & & & & \\
\hline
\end{tabular}

Araştırmada tane için tescil edilmiş Nassau, Balkız, Gina, Bourgondia, Magnum, Başpınar, Romano çeşitleri ile SF08/03 nolu hat kullanılmıştır. Deneme, tesadüf blokları deneme deseninde 3 tekerrürlü olarak kurulmuștur. Ekim; $60 \mathrm{~cm}$ sıra arası, $10 \mathrm{~cm}$ sıra üzeri, $5 \mathrm{~cm}$ ekim derinliğinde, $2.4 \mathrm{~m}$ genişliğinde ve $4 \mathrm{~m}$ uzunluğundaki parsellere 4 sıra olacak şekilde yapılmıştır. Ekim ilk yıl sürekli yağıș ve soğuklar nedeniyle 20 Mayıs 2011 tarihinde, ikinci yıl ise 29 Nisan 2012 tarihinde elle yapılmıştır. Ekim sırasında tüm parsellere $2.6 \mathrm{~kg}$ saf N/da ve $6.5 \mathrm{~kg}$ saf $\mathrm{P}_{2} \mathrm{O}_{5} / \mathrm{da}$ hesabı ile dekara $14 \mathrm{~kg}$ 18-46 DAP (Diamonyum Fosfat) gübresi ekimle birlikte verilmiştir. Deneme alanı ihtiyaç duyuldukça damlama sulama yöntemi ile ilk yıl 6 ikinci yıl 5 kez sulanmıştır. Gerekli olduğu zamanlarda yabancı otlar çapa ile kontrol altına alınmıştır. Çeşitler hasat olgunluğuna geldikçe ayrı ayrı hasat edilmişlerdir. 
Araştırmada her genotipte ekim tarihi ile tohumların \% 50'sinin çıkış yaptığı süre çıkış süresi ve ekim tarihi ile bitkilerin \% 50'sinin çiçeklendiği süre çiçeklenme süresi olarak kaydedilmiştir. Hasat olgunluğu döneminde her parselden tesadüfi olarak 5 bitki seçilerek bitki boyu, ilk bakla yüksekliği, bitkide dal sayısı (ana dal + yan dal toplamı), bitkide bakla sayısı, bitkide tane sayısı, baklada tane sayısı ve bitkide tane verimi belirlenmiştir. Her parselin yanlarından birer sıra ve parsel başlarından 50 cm'lik kısımlar kenar tesiri olarak atılarak geri kalan kısım elle hasat edilerek tarlada kurutulmuş ve tartılarak biyolojik verim ve harmanlamadan sonra dekara tane verimi tespit edilmiştir. Biyolojik verimin tane verimine oranlanması ile \% olarak hasat indeksi hesaplanmıştır. Tane verimi için harmanlanmış olan tanelerden 4 tekrarlamalı olarak yüzer tohum sayılarak tartılmış ve yüz tane ağırlığı belirlenmiștir (Akçin, 1974).

Çizelge 3. Farklı fasulye genotiplerinin incelenen özelliklerine ilişkin varyans analiz sonuçları ve ortalama değerleri

\begin{tabular}{|c|c|c|c|c|c|}
\hline Genotipler & $\begin{array}{c}\text { Çıkış̧ } \\
\text { Süresi (gün) }\end{array}$ & $\begin{array}{l}\text { Çiçeklenme } \\
\text { süresi (gün) }\end{array}$ & $\begin{array}{c}\text { Bitki boyu } \\
(\mathrm{cm})\end{array}$ & $\begin{array}{l}\text { İlk bakla yüksekliği } \\
(\mathrm{cm})\end{array}$ & $\begin{array}{c}\text { Bitkide dal sayısı } \\
\text { (adet) }\end{array}$ \\
\hline 2011 & 18.45 & $50.17 \mathrm{~B}$ & 34.10 & $14.17 \mathrm{~B}$ & $8.71 \mathrm{~A}$ \\
\hline 2012 & 18.58 & $50.33 \mathrm{~A}$ & 35.39 & $17.39 \mathrm{~A}$ & $4.25 \mathrm{~B}$ \\
\hline Ortalama & 18.51 & 51.75 & 34.74 & 15.78 & 6.48 \\
\hline Nassau & 18.33 & $51.00 \mathrm{BC}$ & $26.80 \mathrm{C}$ & $13.39 \mathrm{C}$ & 7.05 \\
\hline Balkız & 17.33 & $49.50 \mathrm{C}$ & $39.52 \mathrm{~A}$ & $15.50 \mathrm{BC}$ & 7.42 \\
\hline Gina & 19.00 & $49.33 \mathrm{C}$ & $39.25 \mathrm{~A}$ & $14.38 \mathrm{C}$ & 6.20 \\
\hline Bourgondia & 18.00 & $56.33 \mathrm{~A}$ & $31.77 \mathrm{~B}$ & $16.47 \mathrm{ABC}$ & 6.75 \\
\hline Magnum & 18.00 & $52.00 \mathrm{BC}$ & $35.93 \mathrm{AB}$ & $19.59 \mathrm{~A}$ & 5.87 \\
\hline Bașpınar & 18.00 & $54.00 \mathrm{AB}$ & $36.30 \mathrm{AB}$ & $17.77 \mathrm{AB}$ & 6.33 \\
\hline Romano-26 & 19.33 & $51.17 \mathrm{BC}$ & $31.77 \mathrm{~B}$ & $14.23 \mathrm{C}$ & 6.06 \\
\hline SF08/03 & 19.67 & $50.67 \mathrm{BC}$ & $36.63 \mathrm{~A}$ & $14.90 \mathrm{BC}$ & 6.17 \\
\hline Ortalama & 18.51 & 51.75 & 34.74 & 15.78 & 6.48 \\
\hline Yillar & öd & $*$ & öd & $* *$ & $* *$ \\
\hline Genotipler & öd & $* *$ & $* *$ & $* *$ & öd \\
\hline Yll x Genotip & öd & $* *$ & $* *$ & öd & $*$ \\
\hline
\end{tabular}

öd: önemli değil *:p $\leq 0.05^{* *}: \mathrm{p} \leq 0.01$

Araştırmamızda genotipler bakımından çıkış süreleri 17.33 ile 19.67 gün arasında değişmiştir. Her iki yılda da ekimden yaklaşı 18 gün sonra \% 50 oranında çıkışlar gerçekleşmiştir. (Çizelge 3). Benzer sonuçlar Elkoca ve Çınar (2015) tarafindan da kaydedilmiştir. Madakbaş ve ark. (2004) fasulyede çıkış süresinin 7-12 gün; Özbekmez (2015) 11.3316.33 gün olduğunu saptamışlardır. $\mathrm{Bu}$ farklı sonuçların nedeninin ilkbaharda toprak sıcaklığı ile ilgili olması muhtemeldir.

Araştırmamızda en uzun çiçeklenme süresi 56.33 gün ile Bourgondia çeşidinde belirlenirken, en erken çiçeklenme 49.33 gün ile Gina çeșidinde saptanmıştır. Çiçeklenme süresi bakımından yıllar arasında fark bulunmamış ve her iki yılda da
Çalışmada elde edilen verilerin varyansları homojen olduğu için yıllara göre birleştirilmiş istatistiksel analizleri "MSTATC" bilgisayar programında yapılmış, önemlilik gösteren özelliklere ait ortalamaların karşılaştırılmasında "AÖF" testi kullanılmıştır.

\section{Bulgular ve Tartışma}

Yllların birlikte analizine ait varyans analiz sonuçlarına göre; çıkış süresi ve bitki boyu hariç incelediğimiz tüm özelliklerde yıllar arasındaki farklılıklar önemli çıkarken, genotipler arasındaki farklılıklarda ise çıkış süresi ve bitkide dal sayısı önemsiz, diğer özellikler ise önemlidir. Yıl x genotip interaksiyonlarında, çıkış süresi, ilk bakla yüksekliği, baklada tane sayısı ve yüz tane ağırlı̆̆ interaksiyonları önemsiz bulunurken incelenen diğer tüm özelliklerde interaksiyonlar istatistiki anlamda önemlidir (Çizelge 3,4,5). çiçeklenme 50 gün içerisinde gerçekleşmiştir (Çizelge 3). İkinci yılda ele alınan genotipler çiçeklenme süresi bakımından farklı tepkiler göstermişler, özellikle Bourgondia çeşidi ikinci yılda uzun bir çiçeklenme süresi gösterirken, birinci yılda ise daha erken çiçeklenmiştir. $\mathrm{Bu}$ nedenle yll $\mathrm{x}$ genotip interaksiyonu önemli çıkmıştır (Şekil 1, A). Fasulyede genotip ve çevre şartlarına bağlı olarak çiçeklenme süresi bakımından farklılıkların gözlendiği birçok araştırıcı tarafından bildirilmektedir. (Anlarsal ve ark., 2000; Madakbaş ve ark., 2004; Elkoca ve Çınar, 2015).

Araștırmamızda en yüksek bitki boyu $39.52 \mathrm{~cm}$ ile Balkız çeşidinde, en düşük değer ise $26.80 \mathrm{~cm}$ ile Nassau çeşidinde saptanmıştır. $39.25 \mathrm{~cm}$ ile Gina çeşidi ve $36.63 \mathrm{~cm}$ ile SF08/03 Balkız çeşidi ile aynı 
istatistiki grup içerisinde yer almıştır. Yılların ortalamasına baktığımız zaman ise her iki yılda da bitki boylarının birbirine çok yakın olduğu görülmektedir (Çizelge 3). İkinci yılda bitki boyu bakımından ele alınan genotipler farklı tepki gösterdiğinden yll $\mathrm{x}$ genotip interaksiyonu önemli bulunmuştur (Şekil 1, B). Fasulyede bitki boyu \%84.6-\%90.0 gibi yüksek bir kalıtım derecesine sahiptir (Çiftçi ve Şehirali, 1984). Bulgularımızla benzer olarak bitki boyu bakımından fasulye çeşitleri ve genotipleri arasında önemli farklılıkların bulunduğu ve bunun genetik yapıdan kaynaklandığı pek çok araştırıcı tarafından bildirilmektedir (Anlarsal ve ark., 2000; Elkoca ve Kantar, 2004; Pekșen, 2005; Ceyhan ve ark., 2009; Babagil ve ark., 2011; Elkoca ve Çınar, 2015).

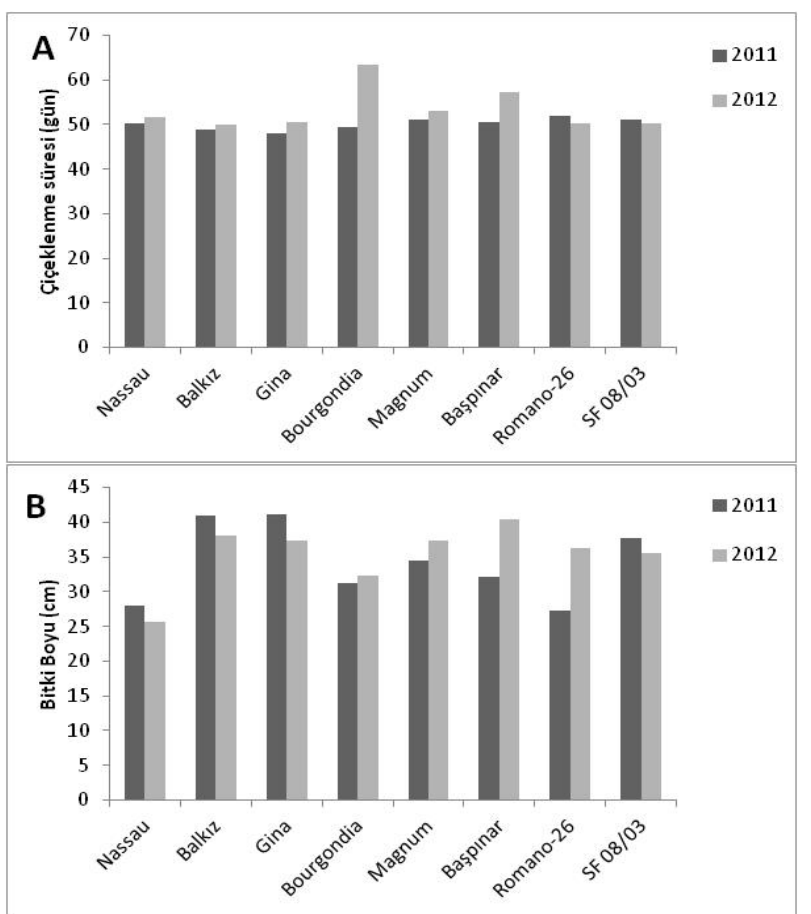

Şekil 1. Çiçeklenme süresi (A) ve bitki boyu (B) bakımından fasulye genotipleri arasındaki interaksiyonlar [LSD \%1:5.532 (A); LSD \%1: $6.838(\mathrm{~B})]$.

İlk bakla yüksekliği bakımından iki yıllık ortalamaya göre, Nassau diğer çeşitlerle kıyaslandığında düşük ilk bakla yüksekliğine $(13.39 \mathrm{~cm})$ sahip olmuştur. Romano-26 ve Gina çeșitleri de ilk bakla yüksekliği düşük olan grup içerisinde yer almıştır. Magnum çeşidi $19.59 \mathrm{~cm}$ ilk bakla yüksekliği ile makineli hasada uygunluk yönünden oldukça dikkat çekici bulunmuștur. Denemenin birinci yılında ilk bakla yükseklikleri ikinci yıla oranla daha düşük olarak belirlenmiştir (Çizelge 3). Farklı ekolojilerde yürütülen değişik çalışmalarda, ilk bakla yüksekliğinin genotipik bir özellik olduğu ve çeşit ve genotiplere bağlı olarak 6.9-19.7 cm arasında olacak şekilde önemli farklılıklar gösterdiği belirlenmiştir (Anlarsal ve ark., 2000; Pekşen, 2005; Babagil ve ark., 2011; Elkoca ve Çınar, 2015).

Fasulye ıslah çalışmalarında çeşit seçiminde üzerinde durulması gereken dal sayısı (Önder, 1994) bakımından genotiplerin dal sayıları 5.87 (Magnum) - 7.42 (Balkız) adet arasında değişmiş ve genotipler arasında önemli farklılıklar belirlenmemiștir. Bitki başına ortalama dal sayısı denemenin birinci yılında 8.71 adet iken ikinci yılda 4.25 adet olarak saptanmış olup yıllar arasındaki farklılıklar istatistiki anlamda önemli bulunmuştur (Çizelge 3). İkinci yılda bazı genotiplerde bitkide dal sayısı azalışı çok fazla olurken bazılarında daha az olmuştur. Bu nedenle yıl $\mathrm{x}$ genotip interaksiyonu önemli bulunmuştur (Şekil 2A). Bitki yetiştirme döneminde ortalama sıcaklıklar ikinci yıl birinci yıla oranla daha yüksek olmuştur (Çizelge 2). Yüksek sıcaklığın etkisi ile bitkide dal sayısının ikinci yıl azaldığı düşünülmektedir. Nitekim konu ile ilgili olarak yıllar arasında bitkide dal sayısı bakımından önemli farklılıkların olduğu ve bu farklılıkların iklimsel faktörlerden kaynaklandığı diğer araştırıcılar tarafından da belirlenmiştir (Pekşen, 2005; Karakuş ve ark., 2005; Elkoca ve Çınar, 2015).

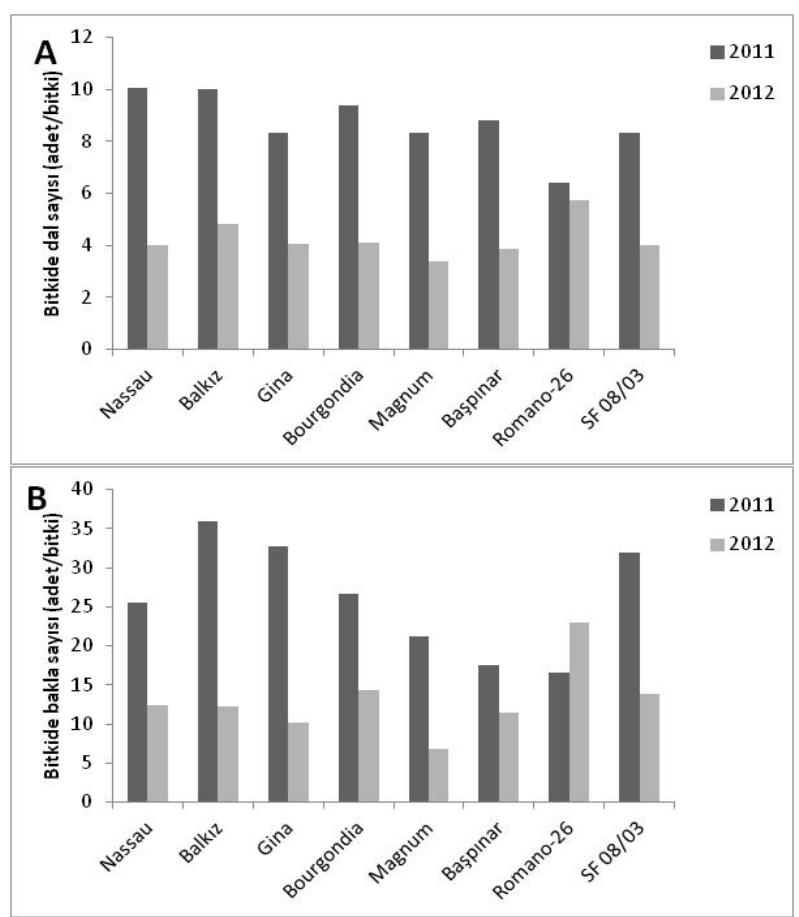

Şekil 2. Bitkide dal sayısı (A) ve bitkide bakla sayısı (B) bakımından fasulye genotipleri arasındaki interaksiyonlar [LSD \%5:1.895 (A); LSD \%1: 7.545 (B)] 
Araștırmamızda önemli verim unsurlarından bitkide bakla sayısı, bitkide tane sayısı ve bitkide tane verimi en yüksek Balkız çeşidinde belirlenirken, baklada tane sayısı en yüksek Başpınar çeşidinde belirlenmiștir. Babagil ve ark. (2011) yapmıș oldukları çalışmalarında baklada tane sayısının genetik yapı ile ilişsili olduğunu belirtmişlerdir. Yaptığımız çalışmada genotipler arasında baklada tane sayısı bakımından belirlenen farklılığın genotipik farklılıktan kaynaklanmış olması muhtemeldir. $\mathrm{Bu}$ önemli verim unsurları araştırmanın birinci yılında ikinci yıla oranla daha yüksek olmuştur (Çizelge 4). Bitkide bakla sayısı ve bitkide tane sayısı bakımından ikinci yıl ele alınan genotiplerin tepkileri farklı olduğundan yıl x genotip interaksiyonu önemli çlkmıştır (Şekil 2, B ve Şekil 3, A). Bitkide tane verimi bakımından ise ikinci yılda bazı genotiplerde bitkide tane verimi azalışı çok fazla olurken bazllarında daha az olmuştur. Bu nedenle yıl x genotip interaksiyonu önemli olmuştur (Şekil 3, B). Araştırmamızda genotiplerin bu önemli verim unsurlarına ait ortalama değerleri birbirinden büyük farklılıklar göstermiştir (Çizelge 4). Bu farklılıkların genetik yapıdan kaynaklandığı düşünülmektedir. Bulgularımızla benzer olarak, Akçin (1974) fasulyede verim ögelerinin yetiştirme koşullarına ve genetik yapıya göre farklılı gösterdiğini bildirmektedir. Diğer bazı araștırıcılar kalıtım derecesi yüksek bir karakter olan baklada tane sayısında çeşit ve genotiplere bağlı olarak önemli farklılıkların olabileceğini bildirilmişlerdir (Elkoca ve Kantar, 2004; Pekşen, 2005; Ülker ve Ceyhan, 2008; Güneş, 2011; Varankaya, 2011). Bozoğlu ve Gülümser (2000) ve Babagil ve ark. (2011) ise bitkide bakla sayısının genotip ve çevre koşullarına bağlı olarak değiştiğini bildirmektedirler. Araştırmamızda Haziran ve Temmuz ayı ortalama sıcaklıkları 2011 yılında uzun yılların ortalamasına yakın gerçekleşmiş ancak 2012 yılında bu aylara ait sıcaklıklar oldukça yüksek olmuştur. Ayrıca nispi nem değerleri ikinci yıl daha düşüktür. Fasulyede generatif dönemin başlangıcı olarak bilinen çiçeklenme ve bakla bağlama dönemleri Haziran ve Temmuz aylarına denk gelmektedir (Çizelge 2). İkinci yıl generatif döneme denk gelen yüksek sıcaklık ve düşük nemin fasulyede çiçeklenmeyi ve döllenmeyi olumsuz etkilediği ve ikinci yılda bu önemli verim unsurlarının düşük olduğu tahmin edilmektedir. Gross ve Kigel (1994), bakla oluşum döneminde yaşanan yüksek sıcaklıkların döllenmeyi olumsuz etkilediği ve buna bağlı olarak daha az sayıda bakla ve tohum oluștuğunu bildirmişlerdir. Bundan dolayı Shonnard ve Gepts (1994), fasulye için yapılan ıslah çalışmalarında sıcağa dayanıklı çeşitlerin geliştirilmesinin önemli olduğuna dikkat çekmiştir. Aytekin ve Çalışkan (2015) fasulyede generatif dönemde yaşanan herhangi bir stresin, diğer dönemlere kiyasla verimde daha fazla kayıplara yol açtığını, tane verimindeki azalmanın bitkide bakla sayısı ve baklada tohum sayısındaki azalmadan kaynaklandığını bildirmektedirler. Bozoğlu ve Gülümser (2000) ile Ülker (2008) bitkide bakla sayısının çevre şartlarından etkilendiğini bildirirken; Anlarsal ve ark. (2000), Elkoca ve Kantar (2004) ile Pekşen (2005) iklimsel faktörlere bağll olarak yıllar arasında bakla sayısı bakımından önemli farklılıklar görülebileceğini bildirmektedirler.

Çizelge 4. Farklı fasulye genotiplerinin incelenen özelliklerine ilişkin varyans analiz sonuçları ve ortalama değerleri.

\begin{tabular}{|c|c|c|c|c|}
\hline Genotipler & $\begin{array}{l}\text { Bitkide bakla sayısı } \\
\text { (adet) }\end{array}$ & $\begin{array}{c}\text { Bitkide tane sayısı } \\
\text { (adet) }\end{array}$ & $\begin{array}{c}\text { Baklada tane sayısı } \\
\text { (adet) }\end{array}$ & Bitkide tane verimi (g) \\
\hline 2011 & $26.01 \mathrm{~A}$ & $111.91 \mathrm{~A}$ & $4.37 \mathrm{~A}$ & $37.28 \mathrm{~A}$ \\
\hline 2012 & $13.03 \mathrm{~B}$ & $49.06 \mathrm{~B}$ & $3.75 \mathrm{~B}$ & $12.34 \mathrm{~B}$ \\
\hline Ortalama & 19.52 & 80.48 & 4.06 & 24.81 \\
\hline Nassau & $18.98 \mathrm{ABC}$ & $75.73 \mathrm{BC}$ & $3.86 \mathrm{BC}$ & $18.95 \mathrm{D}$ \\
\hline Balkız & $24.13 \mathrm{~A}$ & $97.85 \mathrm{~A}$ & $4.01 \mathrm{ABC}$ & $32.93 \mathrm{~A}$ \\
\hline Gina & $21.45 \mathrm{~A}$ & $77.50 \mathrm{BC}$ & $3.39 \mathrm{C}$ & $25.38 \mathrm{BC}$ \\
\hline Bourgondia & $20.49 \mathrm{~A}$ & $91.77 \mathrm{AB}$ & $4.40 \mathrm{AB}$ & $23.98 \mathrm{BCD}$ \\
\hline Magnum & $14.00 \mathrm{C}$ & $64.68 \mathrm{C}$ & $4.30 \mathrm{AB}$ & $24.85 \mathrm{BCD}$ \\
\hline Başpınar & $14.47 \mathrm{BC}$ & $65.90 \mathrm{C}$ & $4.49 \mathrm{~A}$ & $22.30 \mathrm{CD}$ \\
\hline Romano-26 & $19.80 \mathrm{AB}$ & $77.77 \mathrm{BC}$ & $4.02 \mathrm{AB}$ & $21.81 \mathrm{CD}$ \\
\hline SF08/03 & $22.83 \mathrm{~A}$ & $92.70 \mathrm{AB}$ & $4.00 \mathrm{ABC}$ & $28.25 \mathrm{AB}$ \\
\hline Ortalama & 19.52 & 80.48 & 4.06 & 24.81 \\
\hline Yıllar & $*$ & $* *$ & $* *$ & $* *$ \\
\hline Genotipler & $* *$ & $* *$ & $* *$ & $* *$ \\
\hline Yll x Genotip & $* *$ & $* *$ & öd & $* *$ \\
\hline
\end{tabular}

öd: önemli değil *:p $\leq 0.05^{* *}: p \leq 0.01$ 
Araştırmamızda Romano-26 çeşidi \% 32.45 ile en düşük hasat indeksine sahip olurken, \% 39.13 ile Balkız çeşidi ise en yüksek hasat indeksine sahip olmuştur. Diğer genotiplerin hasat indeksleri ise birbirlerine yakın değerler göstermiștir. Genotiplerin ortalaması olarak birinci yıl \%30.89 olan hasat indeksi, ikinci yıl artış göstererek \%39.28'e yükselmiştir (Çizelge 5). İkinci yılda hasat indeksi bakımından ele alınan genotipler farklı tepki gösterdiğinden yll $\mathrm{x}$ genotip interaksiyonu önemli bulunmuştur (Şekil 4, A). Önemli iklim parametrelerinden yağış ve sıcaklığın biyolojik verim ve tane verimi üzerine etkisi çok fazladır. Denemenin yürütüldüğü yıllara ait yağış ve sicaklıktaki farklılıklar biyolojik ve tane verimlerini etkilemiş, hasat indeksi bakımından farklılıkların oluşmasına neden olmuştur (Çizelge 2).

Yemeklik tane baklagillerde yüz tane ağırlığı verim ve pazar kalitesini önemli düzeyde etkilemektedir. Genotipler bakımından yüz tane ağırlı̆̆ı 23.78-37.31 g değerleri arasında değişmiş, en yüksek değer ise Magnum çeşidinde belirlenmiştir (Çizelge 5). Tespit edilen bu farklılığın genotipler arasındaki genetik farklılıktan kaynaklanabileceği düşünülmektedir (Şehirali, 1988). İlk yıl 35.38 g olan ortalama yüz tane ağırlığının ikinci yıl 27.69 g'a gerilediği görülmektedir (Çizelge 5). Araştırmamızın ikinci yılında toplam yağış daha az sıcaklık ise daha yüksektir (Çizelge 2). Yüz tane ağırlığı yüksek kalıtım derecesine sahip bir özellik olup çevre şartlarından özelliklede iklim ve toprak şartlarından çok fazla etkilenmektedir (Çiftçi ve Şehirali, 1984). Aytekin ve Çalışkan (2015) fasulyede generatif dönemde çevresel stresin neden olduğu verim kayıplarının bakla sayısı ile baklada tohum sayısının azalması ve ayrıca tanelerin küçülmesi sonucu meydana geldiğini bildirmektedirler. Anlarsal ve ark. (2000) Çukurova koşullarında bazı fasulye çeşitleri ile yürüttükleri denemelerinde Haziran ve Temmuz aylarında artan sıcaklığa bağlı olarak, yüksek sıcaklığın fasulyede tanenin küçük ve cılız olmasına neden olduğunu bildirmişlerdir. Benzer şekilde Kaçar ve ark. (2004) araştırmalarının ilk yılında çeşitlere ait yüz tane ağırlığını 51.7 g olarak belirlerken, kurak ve sıcak geçen ikinci yılda yüz tane ağırlığının 37.3 g'a kadar azaldığını bildirmișlerdir.

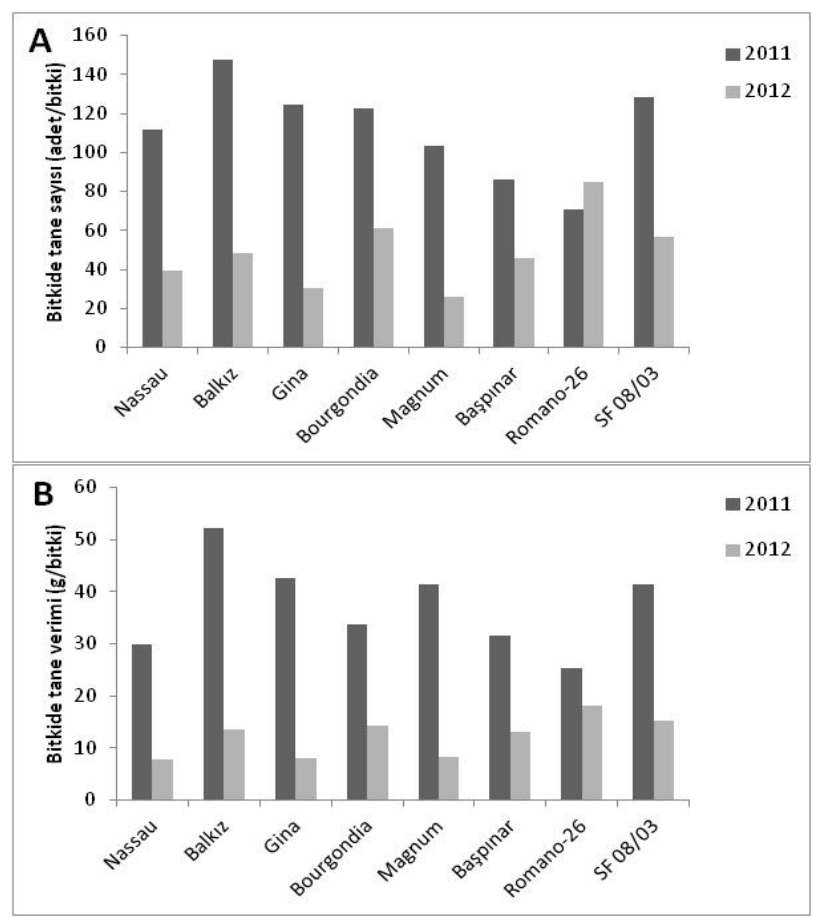

Şekil 3. Bitkide tane sayısı (A) ve bitkide tane verimi (B) bakımından fasulye genotipleri arasındaki interaksiyonlar [LSD \%1:26.812 (A); LSD \%1: 8.382 (B)].

Çizelge 5. Farklı fasulye genotiplerinin incelenen özelliklerine ilişkin varyans analiz sonuçları ve ortalama değerleri.

\begin{tabular}{|c|c|c|c|c|}
\hline Genotipler & Hasat indeksi (\%) & Yüz tane ağırlığı (g) & Biyolojik verim (kg/ha) & Tane verimi (kg/ha) \\
\hline 2011 & $30.89 \mathrm{~B}$ & $35.38 \mathrm{~A}$ & $3058.0 \mathrm{~A}$ & $1194.0 \mathrm{~A}$ \\
\hline 2012 & $39.27 \mathrm{~A}$ & $27.69 \mathrm{~B}$ & $1495.3 \mathrm{~B}$ & $608.6 \mathrm{~B}$ \\
\hline Ortalama & 35.08 & 31.53 & 2276.6 & 901.3 \\
\hline Nassau & $34.97 \mathrm{BC}$ & $23.78 \mathrm{C}$ & $1417.5 \mathrm{D}$ & $598.9 \mathrm{E}$ \\
\hline Balkız & $39.12 \mathrm{~A}$ & $33.75 \mathrm{AB}$ & $2850.6 \mathrm{~A}$ & $1274.7 \mathrm{~A}$ \\
\hline Gina & $35.06 \mathrm{BC}$ & $32.79 \mathrm{AB}$ & $1918.0 \mathrm{CD}$ & $889.9 \mathrm{BCD}$ \\
\hline Bourgondia & $34.06 \mathrm{BC}$ & $27.13 \mathrm{BC}$ & $1960.8 \mathrm{CD}$ & $760.8 \mathrm{CDE}$ \\
\hline Magnum & $35.99 \mathrm{AB}$ & $37.31 \mathrm{~A}$ & $2806.7 \mathrm{~A}$ & $1078.8 \mathrm{AB}$ \\
\hline Başpınar & $34.44 \mathrm{BC}$ & $36.68 \mathrm{~A}$ & $2696.6 \mathrm{AB}$ & $942.2 \mathrm{BC}$ \\
\hline Romano-26 & $32.44 \mathrm{C}$ & $28.23 \mathrm{BC}$ & $2120.5 \mathrm{BC}$ & $700.5 \mathrm{DE}$ \\
\hline SF08/03 & $34.57 \mathrm{BC}$ & $32.62 \mathrm{AB}$ & $2442.3 \mathrm{ABC}$ & $964.9 \mathrm{BC}$ \\
\hline Ortalama & 35.08 & 31.53 & 2276.6 & 901.3 \\
\hline Yillar & $*$ & $* *$ & $* *$ & $*$ \\
\hline Genotipler & $*$ & $* *$ & $* *$ & $* *$ \\
\hline Yll x Genotip & $* *$ & öd & $* *$ & $* *$ \\
\hline
\end{tabular}




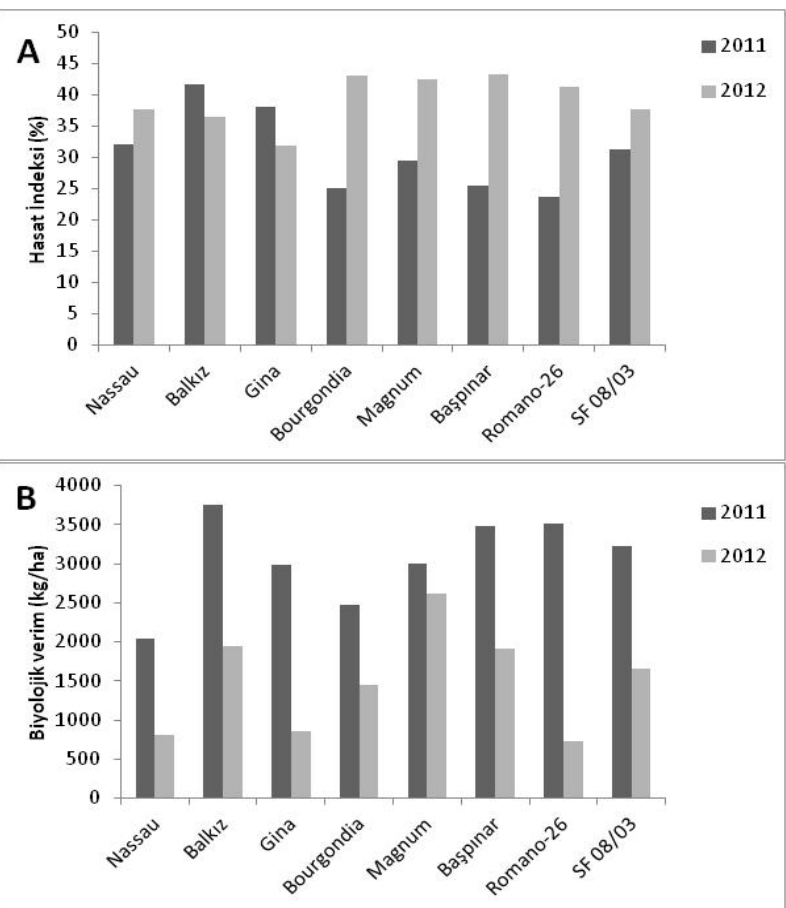

Şekil 4. Hasat indeksi (A) ve biyolojik verim (B) bakımından fasulye genotipleri arasındaki interaksiyonlar [LSD \%1:6.748 (A); LSD $\% 1: 844.16(\mathrm{~B})]$.

Genotiplerin biyolojik verim değerleri ortalama olarak $2276.6 \mathrm{~kg} / \mathrm{ha}$ olmuş, $2850.6 \mathrm{~kg} / \mathrm{ha}$ ile Balkız en yüksek değeri gösterirken, $2806.7 \mathrm{~kg} / \mathrm{ha}$ ile Magnum onu takip etmiş ve bu iki çeşit aynı istatistiki grup içerisinde yer almıştır. Araştırmanın ikinci yılında biyolojik verim değerleri daha düşük olmuştur (Çizelge 5). Bazı genotiplerde biyolojik verimde azalış çok fazla olurken bazılarında daha az olmuştur. $\mathrm{Bu}$ nedenle yll x genotip interaksiyonu önemli çıkmıştır (Şekil 4, B). İki yılın ortalamasına göre Balkız çeşidi en yüksek biyolojik verim değerine sahip olurken, sıcaklığın daha yüksek olduğu ikinci yılda Magnum çeşidi en yüksek değeri göstermiştir (Şekil 4,B). İkinci yılda biyolojik verimde düşüşün az olduğu genotiplerin sıcağa daha dayanıklı olmaları kuvvetle muhtemeldir. Küresel olarak ısınan dünya için iyi bir genetik materyal olabilirler. Genotipler arasında gözlenen bu farklılık ele alınan materyalin genetik farklılığından kaynaklanmıştır. Çiftçi ve Şehirali (1984) genetik yapının biyolojik verim üzerinde önemli bir etkisinin bulunduğunu; Bozoğlu (1995) ise tane verimi ve biyolojik verim arasında pozitif ve önemli bir ilişki belirlediğini bildirmektedir. Araştırmamızın ikinci yılının sıcak geçmesi ikinci yılda biyolojik verimin düşük olmasında etkili olmuştur. Sonuçlarımızla benzer şekilde, yüksek sıcaklıkların fasulye bitkisinin toplam yaprak alanını, toplam kuru ağırlığı ve net asimilasyonunu önemli miktarda azalttığı; yüksek sıcaklığın hücre su içeriğinin kaybına neden olduğu ve sonuçta bitkide büyümenin azaldığı çeşitli araştırıcılar tarafından bildirilmektedir (Rodríguez ve ark., 2005; Ashraf ve Hafeez, 2004).

Ortalama $901.3 \mathrm{~kg} / \mathrm{ha}$ olan tane verimi genotipler arasında 598.9-1274.7 kg/ha arasında değişmiştir. Araştırmanın ilk yılından elde edilen dekara tane verimi değeri ikinci yıla göre daha yüksek olmuştur (Çizelge 5). İkinci yıldaki verim düşüşüne ele alınan genotipler farklı tepki gösterdiğinden yıl x genotip interaksiyonu önemli bulunmuştur (Şekil 5). Magnum çeşidi her iki yılda da benzer üretim performansı göstermesiyle dikkat çekmiştir. Ancak ortalamada en yüksek verimin tespit edildiği Balkız çeşidi ilk yıl en yüksek verimi sağlarken, ikinci yıl Magnum çeşidinin gerisinde kalmıştır ( Şekil 5). Genotipler arasında gözlenen bu farklılığın ele alınan materyallerin genetik farklılığından kaynaklanmış olabileceği düşünülmektedir. Zira benzer şekilde Önder ve Şentürk (1996), Düzdemir (1998) ile Pekşen ve Gülümser (2005) fasulyede çok fazla faktörün genotiplerin verimliliği üzerinde etkili olduğunu ve verimi etkileyen en önemli özelliklerin başında genetik yapının geldiğini bildirmişlerdir. Denemenin ikinci yılında özellikle çiçeklenme ve bakla bağlama döneminin sıcak geçmesi ikinci yıldaki verim düșüklüğünün ana nedeni olmuștur. Çizelge 2'de görülebileceği gibi araştırmamızda Haziran ve Temmuz aylarına ait ortalama sıcaklıklar 2011 yılında uzun yıllar ortalamasına yakın seyrederken 2012 yılında bu aylara ait sicaklıklar daha yüksek olmuştur. Araştırmamızda bu aylar generatif dönemin başlangıcı olan çiçeklenme ve bakla bağlama dönemlerine denk gelmektedir. Warland ve ark. (2006) fasulyede $1.5^{\circ}$ C'lik küçük bir artışın bile ürün verimi üzerinde önemli negatif etkilere sahip olduğunu bildirmektedirler. Elde ettiğimiz sonuçlarla benzer şekilde, fasulyede generatif dönemde yaşanan yüksek sıcaklıkların çiçek ve bakla dökülmesine neden olduğu, tane doldurma dönemlerinde yaşanan yüksek sıcaklıkların ise tanelerin küçük olmasına neden olduğu ve sonuç olarak tane veriminde düşüşlerin meydana geldiği çeşitli araştırıcılar tarafından da bildirilmektedir (Mack ve Singh, 1969; Yaman, 1994). Fasulyede tane verimi çevre şartlarından özelliklede iklim ve toprak şartlarından oldukça 
fazla etkilenmekte (Anlarsal ve ark., 2000; Bozoğlu ve Gülümser, 2000; Ülker ve Ceyhan, 2008) ve sonuç olarak yıllar arasında tane veriminde önemli farklılıklar yașanabilmektedir.

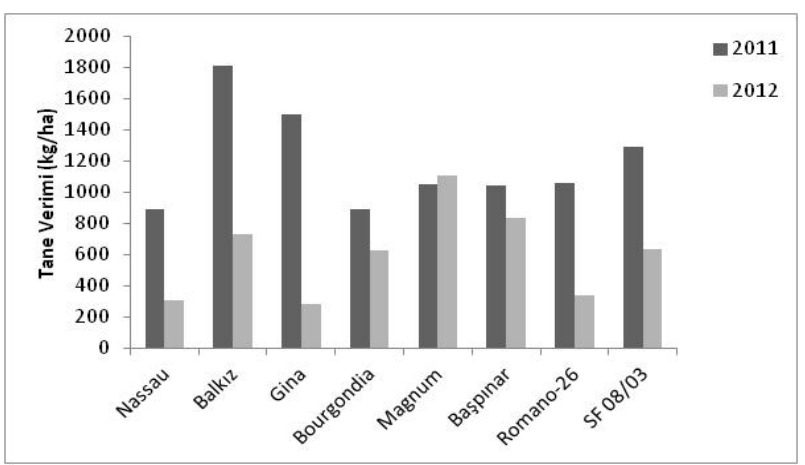

Şekil 5. Tane verimi bakımından fasulye genotipleri arasındaki interaksiyonlar [LSD \%1: 318.85 ].

\section{Sonuç}

Sonuç olarak; Eskişehir ekolojik koşullarına uygun kuru fasulye çeşit/çeşitlerinin belirlenmesi için yürütülen bu çalışmada, önemli verim ve verim unsurları bakımından değerlendirildiğinde en uygun çeşidin Balkız çeşidi olabileceği sonucuna ulaşılmıştır. Araştırmanın ikinci yılında generatif dönemde yaşanan yüksek sıcaklıklar çiçeklenmeyi ve döllenmeyi olumsuz yönde etkilediği için, ilk bakla yüksekliği ve hasat indeksi hariç incelenen tüm özelliklerde daha düşük değerler saptanmıştır. Magnum çeşidi ise önemli verim unsurları bakımından araştırmanın ikinci yılında düşük değerler göstermiş ancak biyolojik verim yüksek sıcaklığa rağmen birinci yıla oranla çok fazla düşmemiş, tane veriminde ise daha yüksek rakamlara ulaşılmıștır. Küresel ısınmanın belirgin bir şekilde hissedildiği bu dönemde bölge koşullarında yapılacak ıslah çalışmalarında Magnum çeşidinin bu özelliğinin değerlendirilebileceği bu araştırma ile ortaya konmuştur. Yüksek verimli Balkız çeşidi ile yüksek sıcaklıklarda tane verimini koruyabilen Magnum çeşidinin melezlenmesinin bölgede fasulye üretiminin artırılmasında katkısı olabileceği düşünülmektedir.

\section{Kaynaklar}

Adak, M.S., Kayan, N., Benlioğlu, B., 2015. Yemeklik tane baklagiller üretiminde değișimler ve yeni arayıșlar. Ziraat Mühendisliği VIII. Teknik Kongresi (12-16 Ocak 2015, Ankara) Bildirileri, 1: 387-399.

Akçin, A., 1974. Erzurum şartlarında yetiştirilen kuru fasulye çeşitlerinde gübreleme, ekim zamanı ve sıra aralığının tane verimine etkisi ile bu çeşitlerin bazı fenolojik, morfolojik ve teknolojik karakterleri üzerine bir araştırma. Atatürk Üniversitesi Ziraat Fakültesi Yayınları, 157: 1-112.

Anlarsal, A.E., Yücel, C., Özveren, D., 2000. Çukurova koşullarında bazı fasulye (Phaseolus vulgaris L.) çeşitlerinde tane verimi ve verimle ilgili özellikler ile bu özellikler arası ilişkilerin saptanması. Turkish J of Agricultural and Forestry, 24: 19-29.

Anonim, 2012. T.C. Tarım ve Köyişleri Bakanlığı Eskişehir Toprak ve Su kaynakları Araştırma Enstitüsü, Toprak Analiz Raporu, Eskişehir.

Ashraf, M., Hafeez, M., 2004. Thermotolerance of pearl millet and maize at early growth stages: Growth and nutrient relations. Biologia Plantarum, 48 (1): 81-86.

Aytekin, R.İ., Çalışkan, S., 2015. Fasulyede büyüme ve gelişme dönemleri. Türk Tarım-Gıda Bilim ve Teknoloji Dergisi, 3 (2): 84-93.

Babagil, G.E., Tozlu, E., Dizikısa, T., 2011. Erzincan ve Hınıs ekolojik koşullarında yetiştirilen bazı kuru fasulye (Phaseolus vulgaris L.) genotiplerinin verim ve verim unsurlarının belirlenmesi. Atatürk Üniversitesi Ziraat Fakültesi Dergisi, 42 (1): 11-17.

Bozoğlu, H., 1995. Kuru Fasulyede (Phaseolus vulgaris L.) Bazı Tarımsal Özelliklerinin Genotip x Çevre İnteraksiyonu ve Kalıtım Derecelerinin Belirlenmesi Üzerine Bir Araştırma. Ondokuz Mayıs Üniversitesi Fen Bilimleri Enstitüsü (Basılmamış), Doktora Tezi, Samsun, $99 \mathrm{~s}$.

Bozoğlu, H., Gülümser, A., 2000. Kuru fasulyede (Phaseolus vulgaris L.) bazı tarımsal özelliklerin genotip çevre interaksiyonları ve stabilitelerinin belirlenmesi üzerine bir araştırma. Turkish Journal of Agriculture and Forestry, 24: 211-220.

Ceyhan, E., Önder, M., Kahramani, A., 2009. Fasulye genotiplerinin bazı tarımsal özelliklerinin belirlenmesi. Selçuk Üniversitesi Selçuk Gıda ve Tarım Bilimleri Dergisi, 23 (49): 67-73.

Çiftçi, C.Y., Şehirali, S., 1984. Fasulye (Phaseolus vulgaris L.) çeşitlerinde değişik özelliklerin fenotipik ve genotipik farklılıklarının saptanması. Ankara Üniversitesi Fen Bilimleri Enstitüsü Yayınları, TB 4:1-17.

Demircan, Ş., 2018. Yüksek Tane Verimli Kuru Fasulye Hatlarının Geliştirilmesi. Selçuk Üniversitesi Fen Bilimleri Enstitüsü (Basılmamış), Yüksek Lisans Tezi, Konya, 39 s.

Düzdemir, O., 1998. Kuru Fasulye (Phaseolus vulgaris L.) Genotiplerinde Verim ve Diğer Bazı Özellikler Üzerine Bir Araştırma. Gaziosmanpaşa Üniversitesi Fen Bilimleri Enstitüsü (Basılmamış), Yüksek Lisans Tezi, Tokat, $64 \mathrm{~s}$. 
Elkoca, E., Kantar, F., 2004. Erzurum ekolojik koşullarına uygun erkenci ve yüksek verimli kuru fasulye (Phaseolus vulgaris L.) genotiplerinin belirlenmesi. Atatürk Üniversitesi Ziraat Fakültesi Dergisi, 35 (34): 137-142.

Elkoca, E., Çınar, T., 2015. Bazı kuru fasulye (Phaseolus vulgaris L.) çeșit ve hatlarının Erzurum ekolojik koşullarına adaptasyonu, tarımsal ve kalite özellikleri. Anadolu Tarım Bilimleri Dergisi, 30: 141-153.

FAO, 2017. http://faostat3.fao.org/browse/Q/QC/E, (Erişim tarihi: 26.12.2018).

Gross, Y., Kigel, J., 1994. Differential sensitivity to high temperature of stages in the reproductive development of common bean (Phaseolus vulgaris L.). Field Crops Research, 36: 201-212.

Güneș, Z., 2011. Van-Gevaş'da Ümitvar Bulunan Fasulye (Phaseolus vulgaris L.) Hatlarında Verim ve Bazı Verim Öğelerinin Belirlenmesi. Yüzüncü Yıl Üniversitesi Fen Bilimleri Enstitüsü (Basılmamış), Yüksek lisans Tezi, Van, $34 \mathrm{~s}$.

Kaçar, O., Çakmak, F., Çöplü, N., Azkan, N., 2004. Bursa koşullarında bazı kuru fasulye çeşitlerinde (Phaseolus vulgaris L.) bakteri aşılama ve değişik azot dozlarının verim ve verim unsurları üzerine etkisinin belirlenmesi. Uludağ Üniversitesi Ziraat Fakültesi Dergisi, 18 (1): 207-218.

Karakuş, M., Çiftçi, V., Toğay, Y., Toğay, N., 2005. Van-Gevaş koşullarında farklı sıra aralıklarının fasulyede (Phaseolus vulgaris L.) verim ve bazı verim öğelerine etkisi. Yüzüncü Yıl Üniversitesi Ziraat Fakültesi Tarım Bilimleri Dergisi, 15 (1): 57-62.

Mack, H.J., Singh, J.N., 1969. Effects of high temperature on yield and carbonhydrat composition of bush snap beans. Journal of the American Society for Horticultural Science, 94: 60-62.

Madakbaş, S.Y., Kar, H., Küçükomuzlu, B., 2004. Çarşamba ovası'nda bazı bodur taze fasulye çeşitlerinin verimliliklerinin belirlenmesi. Gaziosmanpaşa Üniversitesi Ziraat Fakültesi Dergisi, 21 (2): 1-6.

Önder, M., 1994. Bodur kuru fasulye (Phaseolus vulgaris L.) tane verimi ve bazı verim komponentlerinin korelasyon ve path analizi. Türkiye I. Tarla Bitkileri Kongresi (25-29 Nisan 1994, İzmir) Bildirileri, 1: 122-126.

Önder, M., Şentürk, D., 1996. Ekim zamanlarının bodur kuru fasulye çeşitlerinde dane ve protein verimi ile verim unsurlarına etkisi. Selçuk Üniversitesi Ziraat Fakültesi Dergisi, 10 (13): 7-18.

Öner, F., Özkorkmaz Atıcl, F., Yılmaz, N., 2016. Yerel Fasulye (Phaseolus vulgaris L.) genotiplerinde bazı morfolojik özellikler arasındaki ilişkiler ve path analizi. Dicle Üniversitesi Fen Bilimleri Enstitüsü Dergisi, 5 (1):15-18.

Özbekmez, Y., 2015. Ordu Ekolojik Koşullarında Bazı Kuru Fasulye (Phaseolus vulgaris L.) Çeşit ve Genotiplerinin Verim, Verim Ögeleri İle Tohum ve Teknolojik Özelliklerinin Belirlenmesi. Ordu Üniversitesi Fen Bilimleri Enstitüsü (Basılmamış), Yüksek Lisans Tezi, Ordu, 84 s.

Pekşen, E., Gülümser, A., 2005. Bazı fasulye (Phaseolus vulgaris L.) genotiplerinde verim ve verim unsurları arasındaki ilișkiler ve path analizi. Ondokuz Mayıs Üniversitesi Ziraat Fakültesi Dergisi, 20 (3): 82-87.

Pekșen, E., 2005. Samsun koşullarında bazı fasulye (Phaseolus vulgaris L.) genotiplerinin tane verimi ve verimle ilgili özellikler bakımından karşılaștırılması. Ondokuz Mayıs Üniversitesi Ziraat Fakültesi Dergisi, 20 (3): 88-95.

Rodríguez, M., Canales, E., Borrás-Hidalgo, O., 2005. Molecular aspects of abiotic stress in plants. Biotechnology and Applied Biochemistry, 22: 1-10.

Shonnard, G.C., Gepts, P., 1994. Genetics of heat tolerance during reproductive development in common bean. Crop Science, 34: 1168-1175.

Şehirali, S., 1988. Yemeklik Tane Baklagiller. Ankara Üniversitesi Ziraat Fakültesi Yayın No:1089, Ders Kitabı No: 314, Ankara, 435 s.

TUIK, 2017. www.tuik.gov.tr (Erişim tarihi: 26.12.2018).

Ülker, M., Ceyhan, E., 2008. Orta Anadolu ekolojik şartlarında yetiştirilen fasulye (Phaseolus vulgaris L.) genotiplerinin bazı tarımsal özelliklerinin belirlenmesi. Selçuk Üniversitesi Ziraat Fakültesi Dergisi, 22 (46): 77-89.

Ülker, M., 2008. Orta Anadolu Ekolojik Şartlarında Yetiştirilen Fasulye (Phaseolus vulgaris L.) Genotiplerinin Bazı Tarımsal ve Kalite Özelliklerinin Belirlenmesi. Selçuk Üniversitesi Fen Bilimleri Enstitüsü, Yüksek Lisans Tezi, Konya, 81 s.

Varankaya, S., 2011. Yozgat Ekolojik Şartlarında Yetiştirilen Fasulye (Phaseolus vulgaris L.) Genotiplerinin Bazı Tarımsal Özelliklerinin Belirlenmesi. Selçuk Üniversitesi Fen Bilimleri Enstitüsü (Basılmamış), Yüksek Lisans Tezi, Konya, $44 \mathrm{~s}$.

Warland, J.S., McDonald, M.R., McKeown, A.M., 2006. Annual yields of five crops in the family Brassicacae in southern Ontario in relation to weather and climate. Canadian Journal of Plant Science, 86: 1209-1215.

Yaman, M., 1994. Değişik ekim zamanlarının farklı fasulye çeşitlerinde verim ve çiçek dökülmesine etkisi. Türkiye I. Tarla Bitkileri Kongresi (25-29 Nisan 1994, İzmir) Bildirileri, 1: 325-327. 